\title{
UHPLC-DAD-ESI-MS/MS Analysis of Flavonoids from Ethanolic Extracts of Theobroma cacao Husk in Cuba
}

\author{
José González ${ }^{*}$, Danae Pérez², Enrique Gómez¹, Damaris de la C. Salgado¹, Max Monan³ \\ ${ }^{1}$ Departamento de Farmacia, Instituto de Farmacia y Alimentos, Universidad de La Habana, La Coronela, La Lisa, \\ La Habana, Cuba \\ ${ }^{2}$ Departamento de Alimentos, Instituto de Farmacia y Alimentos, Universidad de La Habana, La Coronela, La Lisa, \\ La Habana, Cuba \\ ${ }^{3}$ ARVARNAM, 16 lot. les Rosiers, Quartier Thoraille, Rivière-Salée, Martinica, France \\ Email: ‘jgyaque@ifal.uh.cu
}

How to cite this paper: González, J., Pérez, D., Gómez, E., Salgado, D. de la C. and Monan, M. (2019) UHPLC-DAD-ESI-MS/MS Analysis of Flavonoids from Ethanolic Extracts of Theobroma cacao Husk in Cuba. Open Access Library Journal, 6: e5439.

https://doi.org/10.4236/oalib.1105439

Received: May 5, 2019

Accepted: May 24, 2019

Published: May 27, 2019

Copyright $\odot 2019$ by author(s) and Open Access Library Inc.

This work is licensed under the Creative Commons Attribution International License (CC BY 4.0).

http://creativecommons.org/licenses/by/4.0/

\begin{abstract}
A sample of ethanolic extracts of the husk of Theobroma cacao L. was scrutinized using a UHPLC/DAD/MS Thermo scientific Dionex Ultimate 3000 RS coupled to a Thermo scientific LTQ XL mass spectrometer. In addition, about seven different chemical compounds were tentatively identified in this species based on chromatography retention time (Rt), UV and MS/MS spectra and compared with those of isolated authentic compound and literature data. Information obtained from these studies can be used as markers in the identification and standardization of this plant as a herbal remedy and also towards monograph development on the plant.
\end{abstract}

\section{Subject Areas \\ Plant Science}

\section{Keywords}

UHPLC, MS, Flavonoids, Ethanolic Extracts, Theobroma Cacao

\section{Introduction}

Theobroma cacao L. has been known as "the food of the gods". Cacao tree is wildly grown in tropical and subtropical areas around the world included in Africa, such as Côte d'Ivoire, Ghana, Nigeria, and Cameroon, in American countries, like Brazil, Ecuador, Colombia, and Mexico, in Caribbean and Southwestern Pacific countries, such as the Dominican Republic and Papua New Gui- 
nea, and in Southeast Asian countries, like Indonesia, Malaysia, and Vietnam. Total production of cacao bean is estimated worldwide to be approximately 4.0 million tons in 2013, with a value about $\$ 12$ billion [1].

Native to lowland rainforests of the Amazon and Orinoco river basins, cacao is grown commercially in the New World tropics as well as western Africa and tropical Asia. Its seeds, called cocoa beans, are processed into cocoa powder, cocoa butter, and chocolate as shown in Figure 1 [2].

Residues or wastes from the cacao processing industry consist of cacao pod shell, husk, pulp/mucilage, and hull, which account for a high proportion, approximately $85 \%$ by fresh weight of total cacao pod mass, in which the annual worldwide amount of cacao pod husk is estimated to be about 55 million tons, which is equal to 13 times the total amount of cacao bean [3].

In the cocoa bean industry, some by-products go underutilized. Some of these components could provide other innovative products, and such is the case with the husk of the cocoa bean. Previous studies have attributed the husk with a high antioxidant capacity, which added to its relatively low cost, makes it an attractive ingredient for the production of infusions. However, prior to promoting it as such, its quality needs to be guaranteed [4].

This situation has motivated the development of a lot of studies with the finality of increasing the commercial value and diversifying the use of cacao husks, which traditionally have been utilized as animal food and soil's recovery. In our country, the bean husk is underutilized generating a big number of by-products. Therefore, cacao pod husk needs to be exploited to produce high-value-added products and this waste has been considered as an abundant, inexpensive, and renewable source of polyphenolic compounds like flavonoids, a valuable compound, which exhibit antioxidant activities, that act as a free radicals inhibitor giving potential benefits against the early aging processes [5].

Since ancient times, numerous health beneficial effects have been attributed to chocolate, closing up its consumption to a therapeutic use. Some relevant studies about chocolate (and its bioactive compounds) on some cardiovascular risk factors and stresses underline the need of future studies. The consumption of

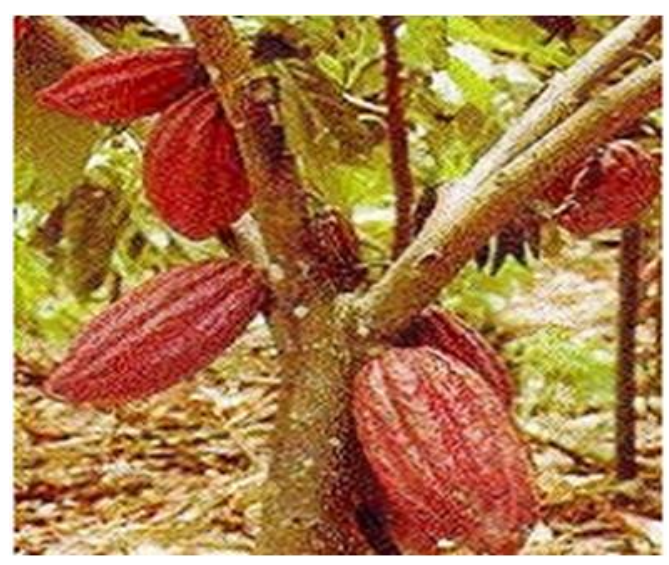

Figure 1. Cacao tree and fruits. 
cocoa/chocolate 1) increases plasma antioxidant capacity, 2) diminishes platelet function and inflammation, and 3) decreases diastolic and systolic arterial pressures. Data currently available indicate that daily consumption of cocoa-rich chocolate (rich in polyphenols) may at least partially lower cardiovascular disease risk. Further studies are required in order to establish the bioavailability and mechanisms of action of bioactive compounds in chocolate [6].

Cocoa husk is composed mainly of polysaccharides (cellulose and hemicellulose) and lignin, along with small quantities of phenolic compounds, tannins, purine alkaloids and cocoa butter [7]. The aim of the present work was to determine qualitatively the flavonoids compounds that are included in cocoa husk as an abundant, inexpensive, renewable, and sustainable source using a non-toxic, accessible, and cheap solvent for potential application in the nutraceutical, medical, and pharmaceutical industries.

\section{Material and Methods}

\subsection{Sample Collection and Processing}

The sample was the husk of cocoa bean after its separation from the beans. It was supplied in 2018 by the Chocolate Factory located in Baracoa, Guantánamo Province, Cuba. After the collection the husks were packet in nylon bags without elimination of foreign matters. The material was grounded in a high-speed hammer mill. Figure 2 shows that the sample keeps its brown color and a very nice chocolate's smell.

\subsection{Extract and Samples Preparation}

The husks used were dried in an oven with controlled temperature at $40^{\circ} \mathrm{C}$, during 5 days. The extracts were prepared with the ground material $(60 \mathrm{~g})$, using a Soxhlet apparatus and $95 \%$ ethanol $(675 \mathrm{~mL})$ for 20 hours, by triplicated. The ethanolic extracts were concentrated and rotoevaporated under vacuum to 200 $\mathrm{mL}$ at $120 \mathrm{rpm}, 70^{\circ} \mathrm{C}$, and $500 \mathrm{mbar}$. The concentrated extract was put on to the Lab table at room temperature until an abundant solid appear and it was recuperated to filtration [8].

\subsection{UHPLC-DAD-ESI-MS/MS Procedures, Instrumentation, and Parameters}

The LC system consisted of an UPLC/DAD/MS Thermo scientific Dionex Ultimate 3000 RS with quaternary pump, autosampler, DAD (diode array detector) Dionex with a UV-VIS at 200 (UV1), 250 (UV2), 280 (UV3), and 330 (UV4) nm, coupled to a mass spectrometer Thermo scientific LTQ XL with ESI (trap ion analyzer) in negative mode. Conditions of detection were optimized with a Tune archive based on the behavior of quercetin. Temperature: $225^{\circ} \mathrm{C}$, Voltage $5 \mathrm{KV}$, Capillar voltage $50 \mathrm{~V}$. Column: Accucore RP-MS $(100 \times 2.1 \mathrm{~mm} \times 2.6 \mu \mathrm{m})$. Temperature: $35^{\circ} \mathrm{C}$. Chromatographic system: eluent ACN: $\mathrm{HCOOH}(0.1 \%)(5 \%$ of $\mathrm{ACN}$ ). Isocratic $20 \mathrm{~min}$. Flow: $0.4 \mathrm{~mL} / \mathrm{min}$. Nitrogen gas flow: 34, auxiliary 


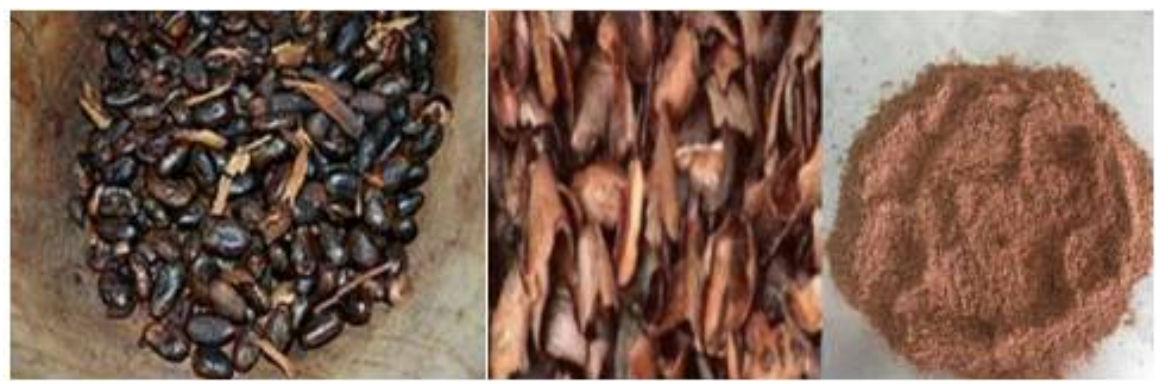

Figure 2. Toasted cacao beans, husk and powered drug.

gas: 16, barrier gas: 3. Induced fragmentation gas: Helium. Was realized an experiment Full Scan in dependent mode to identify the principal ions (TIC) and get the MS and MS'. The sample was dissolved in methanol HPLC grade at 1 $\mathrm{mg} / \mathrm{mL}$ filtered by a nylon filter of $0.20 \mu \mathrm{m}$. Injection volume: $2 \mu \mathrm{L}$. Mass scan between 200 - 700 u.m.a.

\section{Results and Discussion}

Figure 3 shows the TIC chromatogram with the retention times of seven different kind of chemical components present in the sample, indicating that the main compound has purity between $75 \%-80 \%$. All of them were analyzed in negative ion mode.

TIC chromatogram and mass spectrum of each product confirm the presence of seven different chemical compounds, two of them with a molecular mass of $329 \mathrm{Da}$, but with different retention times, at 1.09 and $1.86 \mathrm{~min}$, respectively, indicating that both chemical components are closely related as is shown in Figure 4. Both compounds are related with three quercetin derivatives and/or one ellagic acid derivative. Such compounds were tentatively identified as quercetin 3',7-dimethylether, quercetin 3,7-dimethylether and quercetin 3,3'-dimethyl ether with molecular formula of $\mathrm{C}_{17} \mathrm{H}_{14} \mathrm{O}_{7}$ or $3,3^{\prime}$-di- $O$-methyl ellagic acid, respectively, because of their similar molecular masses $(\mathrm{m} / \mathrm{z} 330)$.

As is shown in Figure 5, the component with molecular mass at $m / z 305$ is closely relative with dihydroquercetin $(m / z$ 304) but it's remaining still unknown. Compound with mass charge at 316 was tentatively characterized as quercetin-3'-metileter (3'-metoxiquercetin) although this molecular mass could be relative with two kaempferol derivatives: 8-metoxikaempferol and kaempferol 6-methyl ether $\left(\mathrm{C}_{16} \mathrm{H}_{12} \mathrm{O}_{7}\right)[9]$.

According with the respective molecular masses, chemical components at 5.33 and 1.11 of retention time remains unknown up to now, but the compound with retention time at $4.67 \mathrm{~min}$ perhaps are closely related with hyperoside or isoquercitrin derivative $(\mathrm{m} / \mathrm{z} 464)$ [10]. The structures of the proposed components are shown in Figure 6.

In this case, there is another possibility to find into ethanolic extracts of $T$. cacao husk two closely chemical compounds that belongs to alkaloids: 8-((3-methylcyclohexyl)oxy)-caffeine and 8-cycloheptyloxy caffeine, respectively, with a molecular mass of $306 \mathrm{Da}$ and molecular formula of $\mathrm{C}_{15} \mathrm{H}_{22} \mathrm{~N}_{4} \mathrm{O}_{3}$ [11]. 


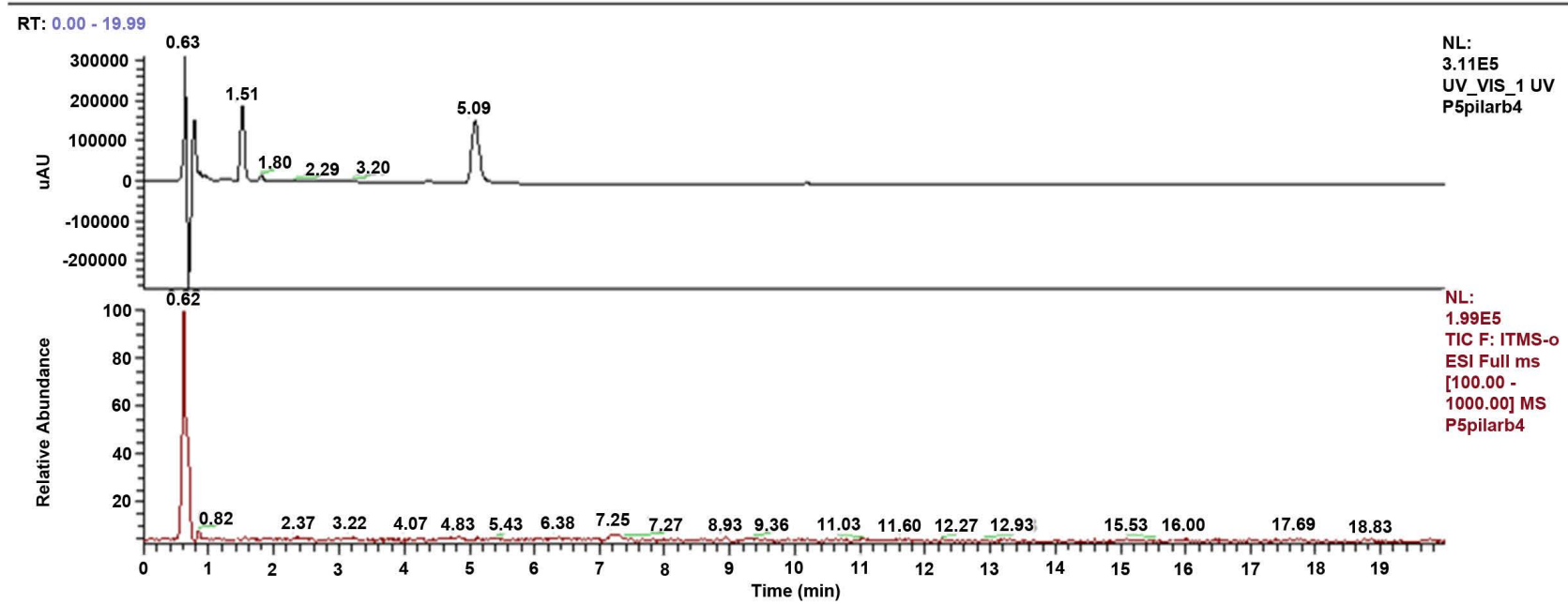

Figure 3. Current chromatogram at $200 \mathrm{~nm}$ of cacao husk sample.

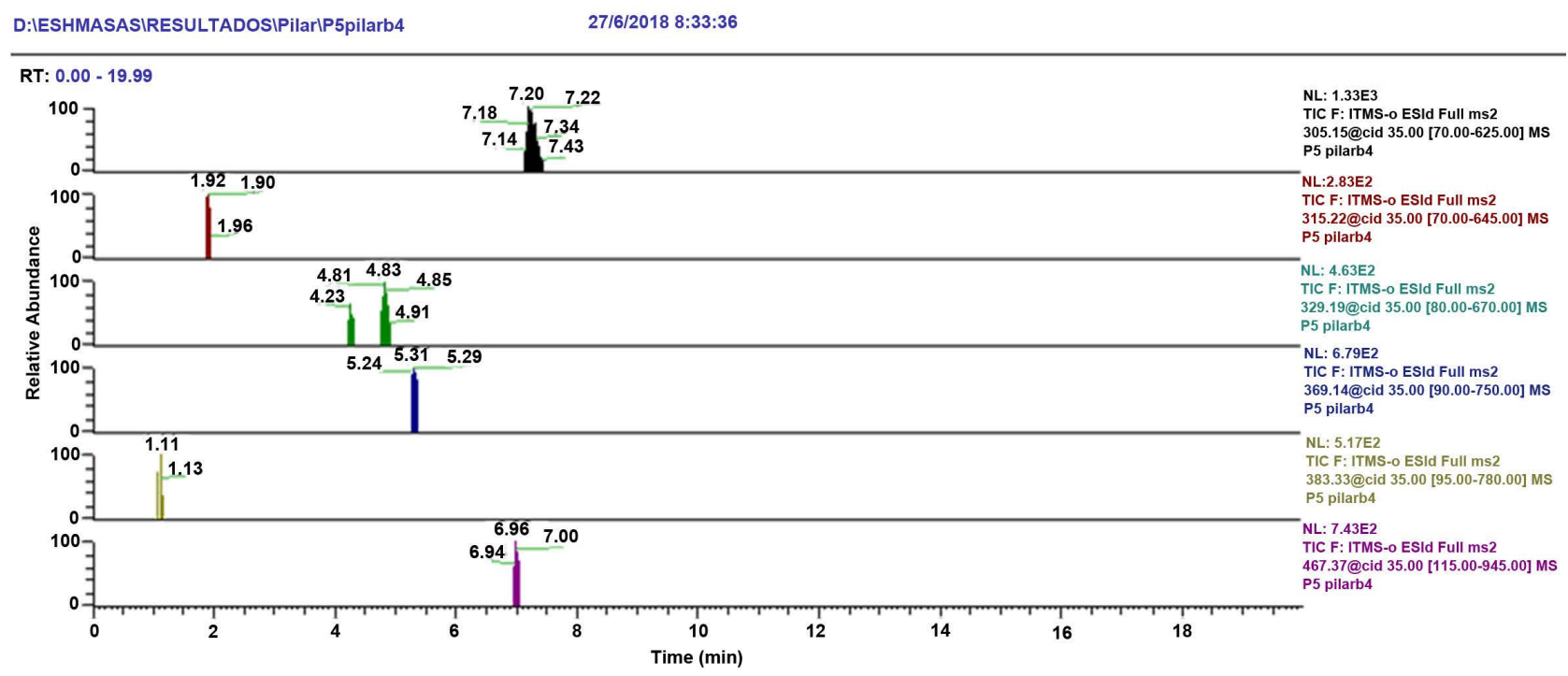

Figure 4. TIC chromatogram and main masses detected.

The flavor and aroma of cacao ( $T$. cacao) beans were the main reasons that promoted its domestication and food-use by pre-Columbian peoples of Mesoamerica. Polyphenols and alkaloids are compounds that directly affect the flavor of the cocoa beans and indirectly on the flavor precursors. The alkaloids are associated with bitterness; its concentration is related to the cultivar and its modifying through the processing. Polyphenols molecules are responsible together with other molecules of the astringency (not desirable in chocolate), but also are responsible for antioxidant properties, very desirable by consumers [12].

\section{Conclusion}

The phytochemical investigation of ethanolic extracts of bean husk from Theobroma cacao L. revealed the presence of seven chemical components probably 


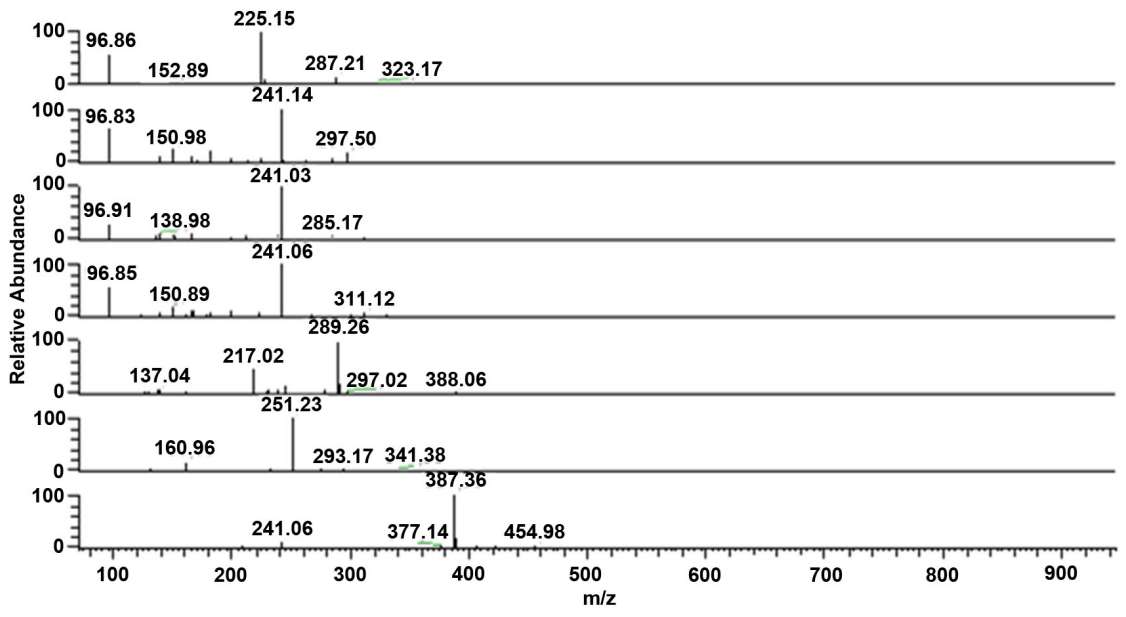

NL: 7.13E2

P5Pilarb4t505 RT: 7.22 AV: 1 F: ITMS - cESI d Full ms2 305.15@cid35.00 [70.00 - 625.00]

NL: 1.03E2

P5pilarb4\#139 RT: 1.92 AV: 1 F: ITMS - cESI d Full ms2 315.22@cid35.00 [75.00 - 645.00]

NL: 1.09E2

P5ilarb4\#139 RT: 4.21 AV: 1 F: ITMS - cESI d Full ms2 329.19@cid35.00 [80.00 - 670.00]

NL: 1.86E2

55ilarb4\#337 RT: 4.83 AV: 1 F: ITMS - cESI d Full ms2 329.19@cid35.00 [80.00 - 670.00]

NL: 2.83E2

. cESI d Full ms2 369.14@cid35.00 [90.00 - 750.00]

NL: 3.42E2

55ilarb4\#375 RT: 1.11 AV: 1 F: ITMS - cESI d Full ms2 383.33@cid35.00 [95.00 - 780.00]

NL: 4.67E2

5pilarb4\#485 RT: 6.98 AV: 1 F: ITMS - cESI d Full ms2 467.37@cid35.00 [115.00 - 945.00]

Figure 5. TIC chromatograms and mass spectrum of each compound.<smiles>O=C1c2c(O)cc(O)cc2OC(c2ccc(O)c(O)c2)C1O</smiles><smiles>COc1cc(-c2oc3cc(O)cc(O)c3c(=O)c2OC)ccc1O</smiles>

dihydroquercetin quercetin-3,3'-dimethyl ether

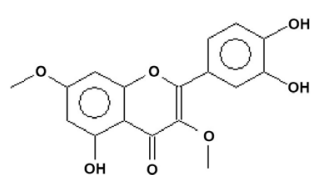

quercetin-3,7-dimethyl ether<smiles>COc1cc(O)c2c(=O)c(O)c(-c3ccc(O)c(OC)c3)oc2c1</smiles>

queretin-3',7-dimethyl ether<smiles>COc1cc2oc(=O)c3cc(O)c(OC)c4oc(=O)c(c1)c2c43</smiles>

3,3'-di-O-methyl ellagic acid<smiles>O=c1c(OC2OC(CO)C(O)C(O)C2O)c(-c2ccc(O)c(O)c2)oc2cc(O)cc(O)c12</smiles>

hyperoside<smiles>COc1cc(-c2oc3cc(O)cc(O)c3c(=O)c2O)ccc1O</smiles>

quercetin-3'-methyleteher

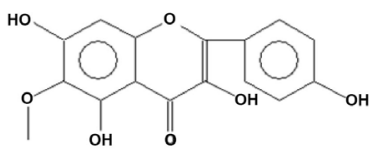

kaempferol 6-methyl ether

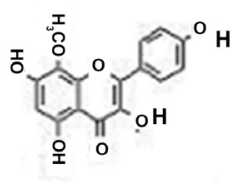

8-metoxykaempferol<smiles>CC1CCCC(Oc2nc3c(c(=O)n(C)c(=O)n3C)n2C)C1</smiles>

8-((3-methylcyclohexyl) oxy)-caffeine

8-Cycloheptyloxycaffeine

Figure 6. Proposal chemical compounds of ethanolic extracts of T. cacao husk.

related with some quercetin derivatives. Natural antioxidants play an important role in front of oxidative stress, possessing antimutagenic, anticarcinogenic, and 
antiinflammatory and neuroprotective effects. These properties could be closely related to phenolic compounds contained in its chemical structures, a variable number of hydroxy groups that react with free radicals. Although some of them are still unknown, this study could be used as a diagnostic tool for the standardization of this medicinal plant and will be helpful in characterization of the crude drug.

\section{Conflicts of Interest}

The authors declare no conflicts of interest regarding the publication of this paper.

\section{References}

[1] FAOSTAT (2017) Cocoa Beans Production in 2016, Crops/World Regions/Cocoa beans/Production Quantity from Pick Lists. United Nations Food and Agriculture Organization, Statistics Division (FAOSTAT).

[2] Cook, L.R. (2018) Cacao Tree. Encyclopedia Britannica.

[3] Nguyen, V.T. and Nguyen, N.H. (2017) Proximate Composition, Extraction, and Purification of Theobromine from Cacao Pod Husk (Theobroma cacao L.). Technologies, 5, 14. https://doi.org/10.3390/technologies5020014

[4] Sangronis, E., Soto, M.J., Valero, Y. and Buscema, I. (2014) Cascarilla de cacao venezolano como materia prima de infusiones. Archivos Latinoamericanos de Nutrición, 64.

[5] Padilla, F.C., Cabrera, A.B. and Andueza, I. (2015) Evaluación de las propiedades antioxidantes y calidad microbiológica de un exfoliante corporal a base de cáscara de cacao (Theobroma cacao). Revista Facultad de Farmacia, 78, 71-76. https://doi.org/10.24054/16927125.v2.n2.2017.2970

[6] Gómez-Juaristi, M., González-Torres, L., Bravo, L., Vaquero, M.P., Bastida, S. and Sánchez-Muniz, F.J. (2011) Efectos beneficiosos del chocolate en la salud cardiovascular. Nutricion Hospitalaria, 26, 289-292.

[7] Franco Agurto Gianella Lisbeth y Suárez Quirumbay Karen Belén (2014) Determinación del Contenido de Polifenoles y Actividad Antioxidante de una Bebida Láctea Elaborada a Base de Residuos Agroindustriales de Cacao, Café y Naranja. TESIS DE GRADO Previa a la obtención del Título de: INGENIERAS EN ALIMENTOS. GUAYAQUIL-ECUADOR. https://doi.org/10.4067/s0718-07642017000400005

[8] González, J., Pérez, D., Gutiérrez, Y.I., Scull, R., Gómez, E., Salgado, D. de la C. and Monan, M. (2018) Pharmacognostic and Physicochemical Studies of Theobroma cacao Bean Husk in Cuba. International Invention of Scientific Journal, 2, 262-267.

[9] González, J., Bécquer, M.A., Soledispa, P.A. and Monan, M. (2018) UHPLC-DAD-ESI-MS/MS Analysis of Gossypitrin Sample from Talipariti elatum (Sw.) with Antioxidant and Neuroprotective Effects. Sumerianz Journal of Agriculture and Veterinary, 1, 70-75.

https://doi.org/10.25125/engineering-journal-ijoer-sep-2017-20

[10] Simirgiotis, M.J. (2013) Antioxidant Capacity and HPLC-DAD-MS Profiling of Chilean Peumo (Cryptocarya alba) Fruits and Comparison with German Peumo (Crataegus monogyna) from Southern Chile. Molecules, 80, 2061-2080. https://doi.org/10.3390/molecules18022061 
[11] Cuéllar García, A.O. (2010) Obtención Del Extracto Polar Etanol: Agua (1:1) de La Cáscara de Cacao y Evaluación de Su Actividad Antibacteriana. Universidad Tecnológica de Pereira, Facultad de Tecnologías, Escuela de Química, Pereira, Colombia. https://doi.org/10.17151/luaz.2017.44.9

[12] Vázquez-Ovando, A., Ovando-Medina, I., Adriano-Anaya, L., Betancur-Ancona, D. and Salvador-Figueroa, M. (2016) Cacao Alkaloids and Polyphenols: Mechanisms That Regulate Their Biosynthesis and Its Implications on the Taste and Aroma. Archivos Latinoamericanos de Nutrición, 66, 239-254.

https://doi.org/10.7287/peerj.preprints.1587v2 